\title{
Pseudomonas aeruginosa as a Potential Contaminant of Packed Fresh-Cut Lettuce in a Controlled Atmosphere.
} The Role of Phenotypes muc $\mathrm{c}^{+} / \mathrm{muc}^{-}$

\author{
Alessandra Scano ${ }^{1}$, Antonio Barberis ${ }^{2}$, Germano Orrù 1,2,*iD , Sara Fais ${ }^{1}$, Francesca Puggioni ${ }^{1}$, \\ Ylenia Spissu 2, Pier Andrea Serra ${ }^{1,3}$, Guy D'hallewin ${ }^{2}$

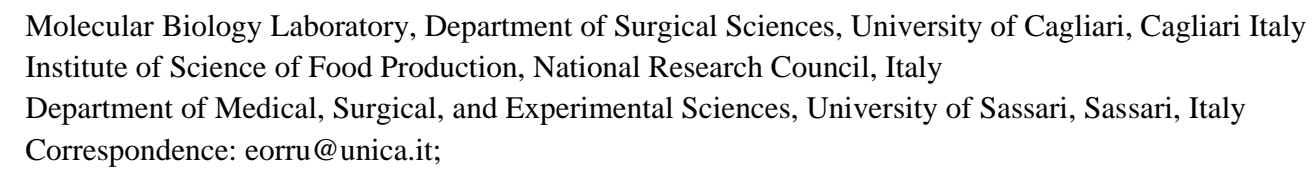

Scopus Author ID 6603502746

Received: 3.07.2020; Revised: 4.08.2020; Accepted: 6.08.2020; Published: 8.08.2020

\begin{abstract}
In order to shed light on contamination risks along the ready-to-eat chain of fresh commodities by emerging foodborne pathogens, we investigated the biofilm development in vitro of two Pseudomonas aeruginosa strains on fresh-cut lettuce (Lactuca sativa L. var. Iceberg). The experiment was performed employing a floating bioreactor system where modified atmosphere package conditions were mimicked, and fresh-cut lettuce disks of $2 \mathrm{~cm}^{2}$ were put into contact with a $10^{6} \mathrm{CFU} / \mathrm{mL}$ of a phenotypic mucoid $P$. aeruginosa phenotype $\left(\mathrm{muc}^{+}\right)$or a non-mucoid one $\left(m u c^{-}\right)$. Following a simulated 2-day refrigerated-shelf quantitative Real-Time PCR, designed on a target gene region of the $16 \mathrm{~S}$ rRNA gene, defined the different $m u c$ phenotypes behavior on biofilm in lettuce phyllo-plane. Between the two strains, a development difference of nearly $1.0 \log \mathrm{CFU} / \mathrm{cm}^{2}$ occurred, with the $m u c^{+}$ phenotype being the most settled and adherent. This result clearly showed a distinct contamination risk according to $P$. aeruginosa phenotype and the need to develop real-time, specific, fast, and easy to use detection protocols along with specific sanitation systems for modified atmosphere package ready-toeat commodities.
\end{abstract}

Keywords: ready-to-eat produce; emerging foodborne agents; biofilms; mucA gene; exopolysaccharide alginate.

(C) 2020 by the authors. This article is an open-access article distributed under the terms and conditions of the Creative Commons Attribution (CC BY) license (https://creativecommons.org/licenses/by/4.0/).

\section{Introduction}

Today's lifestyles and health concerns have led to a significant rise in fruit and vegetable consumption balanced by a remarkable growth of ready-to-eat (RTE) products on the market [1]. Within this context, fresh-cut produce is acquiring a crucial role thanks to its fresh-like appearance, taste, flavor, and handiness. Still, the primary and secondary phase of the RTE production faces unsolved criticisms related to the product's short shelf-life and safety issues [2]. Indeed, following harvest senescence hasten in most crops and processing ensuing steps (grading, washing, peeling, cutting, and packaging) further speed up quality spoilage. In addition, the extracellular release of cytoplasm nutrients, following cell-wall ruptures by cutting, provides a favorable milieu for the fast growth of foodborne pathogens, especially bacteria and yeast [3]. Since fresh-cut commodities, such as leafy greens (e.g., lettuce, parsley, etc.) and fruit salads, are consumed raw, they represent a potential transmission vehicle for human chronic infections [4]. To withstand those threats, fresh-cut produce is sanitized, packed 
into a modified atmosphere, and kept refrigerated [5]. Ongoing researches to withstand the outbreak of resistant strains is constantly reporting on new treatments, more effective, and differently acting $[6,7]$. However, outbreaks of foodborne diseases start frequently by an overreliance on the food safety management system [8]. Along the food chain, all steps have a strict interdependence, and contamination risk assessment must start from the field to warrant quality and safety at all subsequent stages [9]. In addition, the increasing need to use wastewater in agriculture and the occurrence of groundwater contamination introduce new critical issues [10]. The latter influence the microbial load introduced by fresh produce into the processing line affecting the cross-contamination risk significantly. Holvoet et al. [11] evidenced that aboveaverage microbial loads at harvest, increase cross-contamination, and total psychrotrophic aerobic bacterial count resulted in useless as a food safety indicator. In addition, planktonic and biofilm bacterial cells have different susceptibility to disinfectants as well as attachment characteristics to food or processing equipment surfaces [12, 13]. This complex microbeproduce interaction and the development of disinfectant-resistant strains hurry-up the need for easy, efficient, and fast methods to detect and map early microbial settlements along the chain. In this regard, medical research has developed several methods; however, most are invasive, costly, time-consuming, need specialized labs, and trained personnel. In addition, yet they have not been applied along the farm-to-fork chain to warn on over-all microbial composition [14, 15]. According to recent statistics on foodborne illnesses in the USA and the European Union, among the over 250-reported foodborne diseases, leafy vegetables are implicated in several outbreaks, and most common agents are Norovirus, Salmonella spp., and Escherichia coli [16]. Still, other opportunistic ubiquitous pathogens with high adaptation capacity and resistance towards sanitation treatments are increasingly involved in acute and chronic infections related to food contamination [17, 18]. Emerging foodborne outbreaks, like those involving Pseudomonades, are strictly related to cropping environment, processing protocols, as well as diet changes, all factors influencing the background microflora balance [19, 20]. In this respect, the World Health Organization ranks Pseudomonas aeruginosa as critical due to its high antibiotic resistance and a broad range of adaptive mechanisms [21]. Among adaptations occurring in $P$. aeruginosa subjected to biotic/abiotic stresses, quorum sensing is pivotal to switch from the planktonic form to the more resistant and adherent biofilm one [22]. Little literature on $P$. aeruginosa behavior under abiotic stresses such as the ones occurring along the fresh-cut chain (sanitation, nutrient/oxygen variation, low temperature) is available [23]. For this reason, the effect of mimicked fresh-cut lettuce package conditions on the development of two $P$. aeruginosa phenotypes was investigated by a feasible detection methodology.

\section{Materials and Methods}

\subsection{Lettuce leaf sample preparation and bioreactor structure.}

Freshly harvested lettuce heads (Lactuca sativa cv 'Iceberg') were attained from a local farm producing leafy greens addressed to the processing industry (Fresco \& Pronto S.r.l., Monserrato (CA), Italy). In order to simulate the local commercial chain for fresh-cut produce, lettuce heads were immediately moved from the field to the laboratory, soiled external leaves discarded and then, recovered leaves were dumped into a cold-water-sodium hypochlorite solution $\left(4^{\circ} \mathrm{C} ; 50 \mathrm{mg} \mathrm{L}^{-1}\right.$ total chlorine). The disinfection process lasted for $15 \mathrm{~min}$ by gently shacking the bath. After removal, leaves were rinsed with sterile water and drained by means of a vegetable-centrifuge. Finally, the middle area of unbruised lettuce leaves was used to 
prepare tissue disks employing a cork-borer $(\varnothing 1.5 \mathrm{~cm})$ under sterile conditions. Disks were gently rinsed with deionized water and kept cold $\left(4{ }^{\circ} \mathrm{C}\right)$ until use (max one h).

In order to obtain comparable and replicable results, a specific growth-monitoring system was developed, owning a temperature $\left(0-25 \pm 1^{\circ} \mathrm{C}\right)$ and oxygen level $(1-0.5 \mathrm{kPa})$ control. In addition, the contact area between $P$. aeruginosa cells and the lettuce phylloplane was standardized in order to monitor bacterial growth according to a specific leaf area. In this work, bacterial growth occurred in a floating bioreactor system (Fig. 1), where the contact area between $P$. aeruginosa cell suspension and the leaf surfaces was set at $2 \mathrm{~cm}^{2}$. The floatingbioreactor system was developed with the aim to study microbe-host adhesion at the laboratory level, applying comparable settings to those occurring during standard shelf-life conditions of Modified Atmosphere Packed (MAP) fresh-cut produce [24].

\subsection{Pseudomonas aeruginosa phenotypes, storage, and preparation.}

Experiments were performed with two reference $P$. aeruginosa strains: a mucoid phenotype, alginate producer (ATCC 15442) highly biocide-resistant $\left(m u c^{+}\right)$, and a nonmucoid one (ATCC 2783$)$ highly susceptible $\left(m u c^{-}\right)$. Until used, both isolates were stored in stock-vails $(50 \mu \mathrm{L})$ in a tryptic soy agar (TSA) medium with $15 \%$ glycerol at $-80{ }^{\circ} \mathrm{C}$ (Microbiol Uta, Italy). Before each experiment, a stock of the frozen bacterial culture was slowly thawed and plated on TSA medium. Following $24 \mathrm{~h}$ incubation at $37{ }^{\circ} \mathrm{C}$, a single colony was removed and inoculated into a $500 \mathrm{~mL}$ flask with sterilized Mueller Hinton Broth (Microbiol, Cagliari, Italy) and incubated at $37^{\circ} \mathrm{C}$ for eight $\mathrm{h}$, until the growth middle logarithmic phase was reached $[25,26]$. Then, for each $P$. aeruginosa strain, a final concentration of $10^{6} \mathrm{CFU} / \mathrm{mL}$ bacterial cell was prepared and employed as the starting inoculum for the $2 \mathrm{~cm}^{2}$ lettuce leaf specimen placed in the floating bioreactor system.

\subsection{DNA extraction.}

Following $48 \mathrm{~h}$ of the simulated MAP conditions, the leave specimens were removed from the floating bioreactor, and a $1 \mathrm{~cm}^{2}$ circle, from the center of each leaf-specimen, was removed by a cork-borer $(8 \mathrm{~mm} \varnothing)$ and employed to obtain $P$. aeruginosa DNA. The extraction of microbial DNA was achieved by the hexadecyltrimethylammonium bromide (CTAB) protocol. In short, leave tissue was chopped (with a stainless blade), suspended in $400 \mu \mathrm{L}$ of ultrapure water DNAse free (Gibco, Invitrogen Paisley, Scotland UK) and ground thoroughly using an Ultra TURRAX ${ }^{\circledR}$ - Tube Drive (IKA, Germany) with sterile glass balls for 3 min at shaking power 7 . Subsequently, $70 \mu \mathrm{L}$ of a $10 \%$ sodium dodecyl sulfate solution (SDS) and five $\mu \mathrm{L}$ of proteinase $\mathrm{K}(10 \mathrm{mg} / \mathrm{mL})$ (Sigma-Aldrich, ST. Louis, Missouri, USA) were added and vortexed ( $2 \mathrm{~min}$ high speed), then the resulting mixture was incubated for $10 \mathrm{~min}$ at $65{ }^{\circ} \mathrm{C}$. Following incubation, $100 \mu \mathrm{L}$ of $\mathrm{NaCl}[5 \mathrm{M}]$ and $100 \mu \mathrm{L}$ of $\mathrm{CTAB} / \mathrm{NaCl}(0.274 \mathrm{M} \mathrm{CTAB}$ and $0.877 \mathrm{M} \mathrm{NaCl}$, Sigma-Aldrich) were added to the vial, vortexed and incubated at $65^{\circ} \mathrm{C}$ for 10 min. After incubation, $750 \mu \mathrm{L}$ of SEVAG (Chloroform: Isoamyl alcohol-v:v; 24:1, SigmaAldrich) was added, and the mixture was medium speed vortexed for $10 \mathrm{sec}$. Then, the mixture was centrifuged ( $5 \mathrm{~min}$ at $5600 \mathrm{RCF}$ ), and 0.6 volumes of isopropanol (Sigma-Aldrich) were added to the supernatant, which was stored at $-20{ }^{\circ} \mathrm{C}$ for $30 \mathrm{~min}$. The cooled mixture was centrifuged ( $30 \mathrm{~min}$. at $5600 \mathrm{RCF}$ ), the pellet recovered and left to dry at room temperature for $20 \mathrm{~min}$. Afterward, the dried pellet was suspended in $20 \mu \mathrm{L}$ of molecular biology-grade distilled 
water (Gibco, Invitrogen Paisley), vortexed, and two $\mu \mathrm{L}$ of it was used as DNA suspension for the real-time PCR reaction.

\subsection{Real-time PCR conditions and quantitation curve.}

The total mass of the two investigated $P$. aeruginosa phenotypes (muc- or muc+) developed within $48 \mathrm{~h}$ on the lettuce leave surface under MAP conditions at $4^{\circ} \mathrm{C}$ was determined through the method reported by Denotti et al.[27]. Briefly, a real-time PCR (RTPCR) protocol was performed by using the Light Cycler instrument with the Light Cycler DNA Master SYBR Green I kit (Roche Diagnostics, Mannheim, Germany). PCR reaction involved a region of the 16S rRNA gene. The primers for the PCR OG644 (5'GGGAGGAAGGGCAGTAAGTT - 3') and OG645 (5'-ACCACCCTCTACCGTACTCT3') were designed to a flanking sequence of $228 \mathrm{bp}$ (GenBank accession AJ549293) by using Primer3web program .version 4.1.0. The PCR profile was as follows: (i) denaturation at 95 ${ }^{\circ} \mathrm{C}$ for $30 \mathrm{~s}$ and (iii) 40 cycles of $1 \mathrm{~s}$ at $95^{\circ} \mathrm{C}, 10 \mathrm{~s}$ at $50^{\circ} \mathrm{C}, 3 \mathrm{~s}$ at $72^{\circ} \mathrm{C}$ and $3 \mathrm{~s}$ at $81^{\circ} \mathrm{C}$. (iv) The melting curve was performed for $1 \mathrm{~s}$ at 95,45 , and $95^{\circ} \mathrm{C}$. Transition rates were: $5^{\circ} \mathrm{C} / \mathrm{s}$ in $72{ }^{\circ} \mathrm{C}$ segment, $0.1{ }^{\circ} \mathrm{C} / \mathrm{s}$ in $45{ }^{\circ} \mathrm{C}$ segment and $20{ }^{\circ} \mathrm{C} / \mathrm{s}$ for another step. Fluorescence was detected at the end of the $81{ }^{\circ} \mathrm{C}$ segment (avoiding aspecific fluorescence due to primer-dimers, in the PCR step (single mode) and at $45^{\circ} \mathrm{C}$ segment in the melting step (continuous mode) in the F1 channel. (Figure 2). P. aeruginosa cells amount was evaluated in the lettuce leaves by a standard curve made on DNA extracts obtained from different $P$. aeruginosa cell suspensions with a concentration ranges from $10^{6}$ to $10^{2}$ genomes/ $\mu$ l. The amount of bacterial DNA concentration in the leaf extracts was calculated by an interpolated threshold cycle with a standard curve (Figure 3). The prediction in silico of melting temperatures was evaluated by using $\mathrm{m}$ To evaluate $P$. aeruginosa adhesion index, we have used the subsequent equation [27]:

$$
\mathrm{AI}^{\circ}=\left([\mathrm{DNA}]^{*} \mathrm{~V}^{\circ} / 2\right) / \mathrm{S}^{\circ}
$$

$\mathrm{AI}^{\circ}$ is the bacterial adhesion coefficient measured in $P$. aeruginosa genomes $/ \mathrm{cm}^{2}$ on a lettuce leaf surface.

[DNA] $=$ bacterial genomes in $2 \mu \mathrm{l}$, calculated by PCR real-time standard curve interpolation. $\mathrm{V}^{\circ}=$ volume of DNA extract suspension $(50 \mu \mathrm{l}$ during our experiments $) . \mathrm{S}^{\circ}=$ leaf surface used for DNA extraction $\left(1 \mathrm{~cm}^{2}\right)$.

\subsection{Statistical analysis.}

The absolute quantification of total bacteria with RT-PCR was performed by Escherichia coli standard curve following a previously published protocol [27]. In these experiments, the standard curve linear correlation $\mathrm{R}^{2}$ ranged from 0.97 to 0.99 . For each analysis, three distinct biological replicas were made, and quantitative data were expressed as values mean $\pm \mathrm{SD}$. For each sample, the threshold cycle variation comprises \pm 0.8 was considered significant. The growth and adhesion were compared in muc- and muc+ experimental groups by using Fisher's exact test. Data were considered statistically significant for $P \leq 0.05$. 


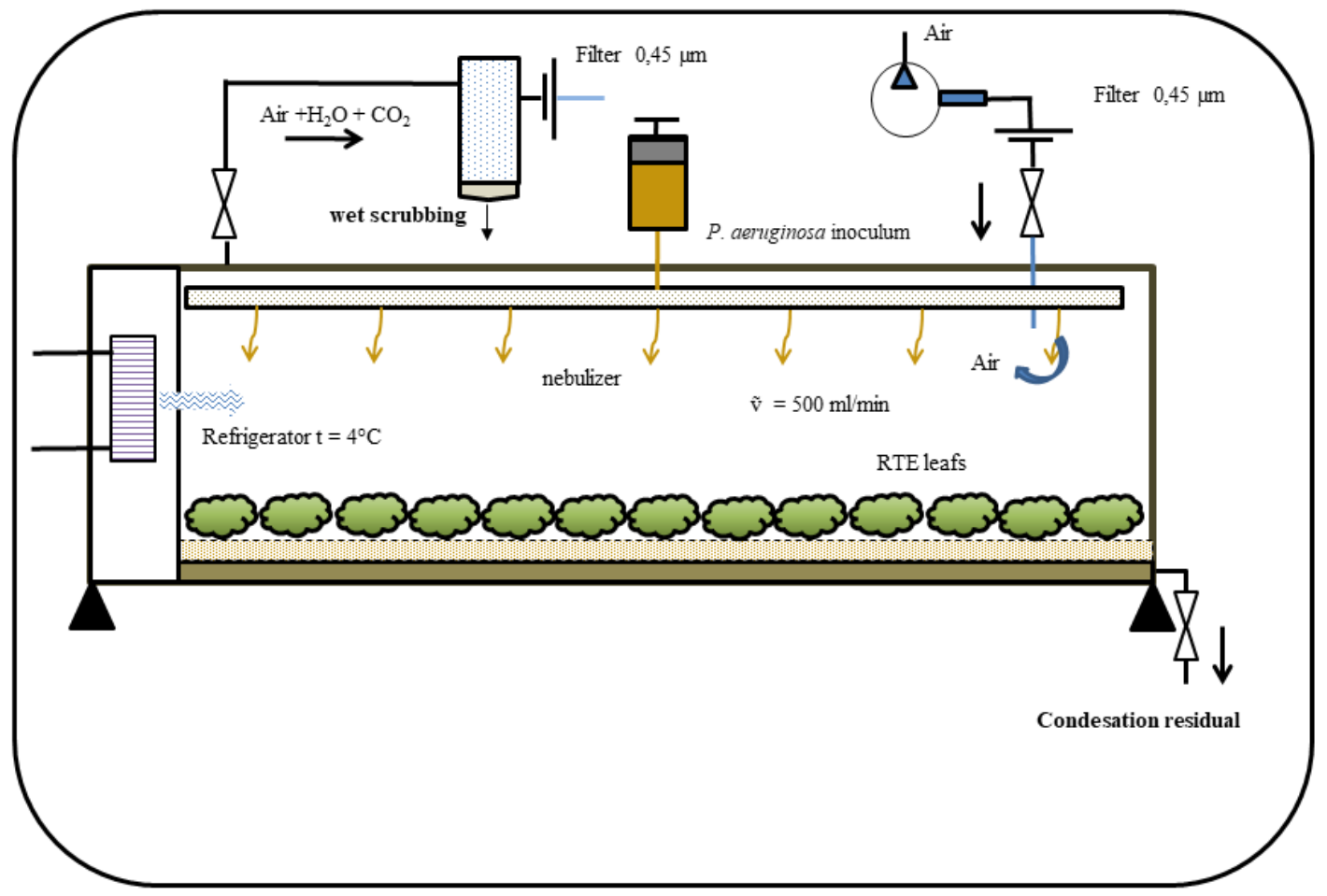

Figure 1. Schematic diagram of the floating bioreactor system used to simulate the contamination of fresh-cut ready to eat (RTE) lettuce by $P$. aeruginosa (mис+/muc-) when kept under MAP conditions. Leaf contactsurface was of $2 \mathrm{~cm}^{2}$, and the sterile water volume $100 \mathrm{~mL}$.

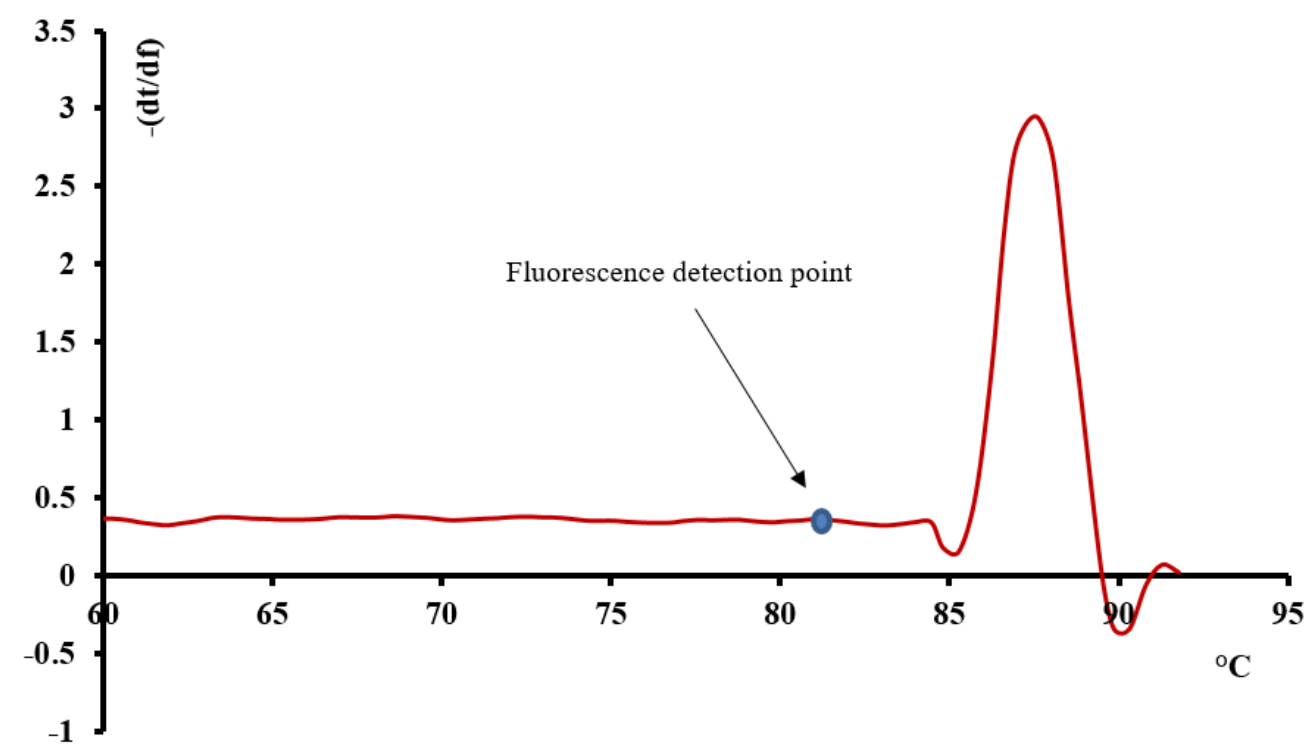

Figure 2. Melting curve profile obtained by light Cycle real-time PCR by using a $P$. aeruginosa ATCC 15442 DNA extract, positive sample showed a unique melting peak at $87.5^{\circ} \mathrm{C}$, in accordance with the values calculated in silico by the DNAmelt program.

\section{Results and Discussion}

According to the RT-PCR analysis, the development of $P$. aeruginosa muc+ and mucon lettuce surface kept under MAP conditions was quite different following $48 \mathrm{~h}$ of storage (Figure 4). Colonization degree between the two phenotypes reached a difference of approximately $1 \log (P<0.05)$, with $m u c+$ attaining over $1 \times 10^{9} P$. aeruginosa genomes $/ \mathrm{cm}^{2}$ (Figure 4). Thus, results achieved by this research display a notable difference between the colonization and adhesion behavior of the two reference phenotypes used in this simulated 
contamination experiment of fresh-cut produce. In particular, muc+ (ATCC 15442) increased the phylloplane-biofilm by $3 \operatorname{logs}$ within $48 \mathrm{~h}$. This result agrees with Holvoet et al. [11], evidencing how, under standard processing and shelf-life conditions, applied to fresh-cut ready-to-eat vegetables, the initial microbial load is critical, especially for muc+ phenotypes. Thus, the increased occurrence of contaminated irrigation/processing water with $m u c+$ strains jeopardizes the sanitation system and increases the need to establish critical control points for hazard analysis along the processing line [8]. In addition, most water-sanitation protocols are based on the total coliforms count, which should be revised, taking into account emerging pathogens resistant to most used disinfectants $[26,28]$.

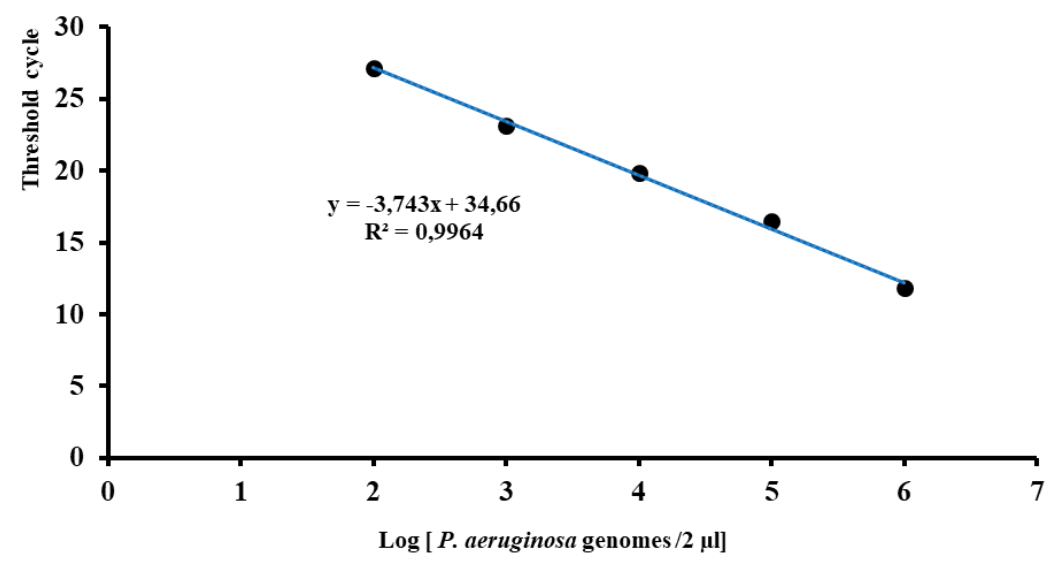

Figure 3. Real-time PCR standard curve related to serially diluted suspensions of $P$. aeruginosa cells. In these conditions, the linear dynamic range of quantification was observed in the range of $10^{2}-10^{6}$ bacterial genomes $/ 2 \mu \mathrm{l}$, corresponding to $5 * 10^{3}-5 * 10^{8} \mathrm{CFU} / \mathrm{mL}$.

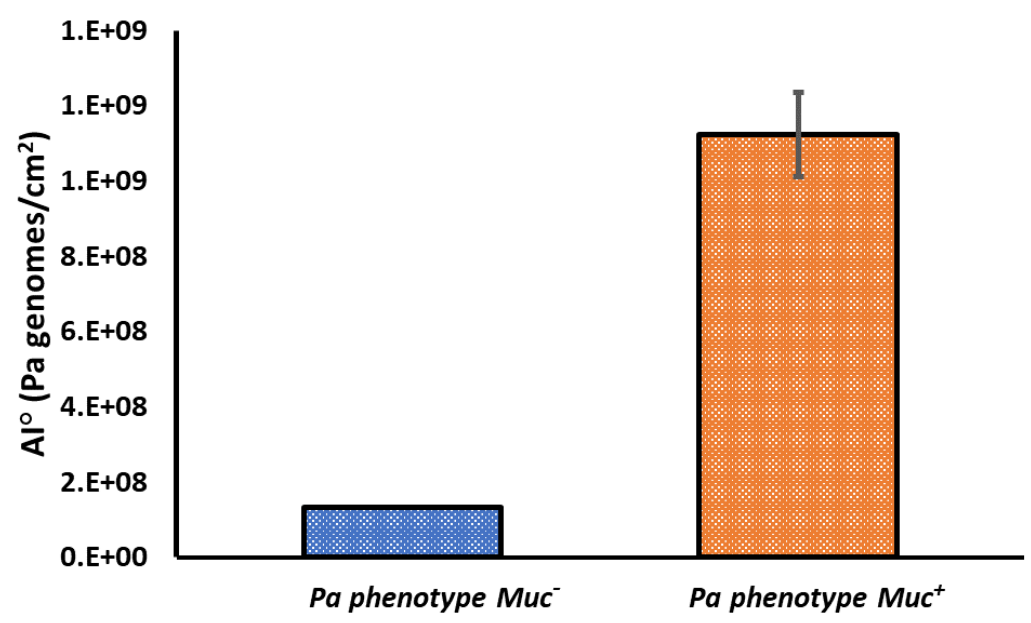

Figure 4. Mean of biofilm amount between $m u c-$ and $m u c+$ phenotypes as determined by real-time PCR and expressed as adhesion index (AI), total genomes of $P$. aeruginosa per $\mathrm{cm}^{2}$ of $L$. sativa leaf kept under modified atmosphere conditions at $4{ }^{\circ} \mathrm{C}$ for 48 hours.

\section{Conclusions}

Special considerations must be given to the ready-to-eat chain of fresh-cut produce in that sanitation is threatened by produce perishability and structure (surface anatomy, cuts, epicuticular waxes, etc.), as well as cross-contamination (lack of appropriate commodity hazard assessment) and increased recycling of water $[10,13,17,18]$. All of these criticisms are favorable to the outbreak of foodborne agents, especially when the cold-chain is not maintained 
along with the post-processing phase. The spread of several foodborne diseases is halted by low temperatures, but short warm-ups may defeat microbial safety, as evidenced by E. coli acid-resistant isolates [29]. Still, the present work evidence that also under cold and subatmospheric oxygen partial pressure conditions, the muc+ phenotype of $P$. aeruginosa was able to grow and colonize lettuce phylloplane in a relatively short period $(48 \mathrm{~h})$, considering the commercial 5 to $7 \mathrm{~d}$ shelf-life for fresh-cut produce. This result is likely related to the mutation of the mucA gen, which is a negative regulator of the extracytoplasmic sigma-factor $\sigma 22$, responsible for the overproduction of alginate [30]. The resistance role of alginate in $P$. aeruginosa's biofilm formation during the infection process has been explained by Lim J. et al. [31] in cystic fibrosis and evidence of how alginate significantly contributes to strengthen the biofilm structure and increase the stickiness to surfaces. Thus, this observation, along with the results reported by Worlitzsch et al. [32] on P. aeruginosa muc+ resistance to low oxygen levels, corroborates the results of the present research. The capacity of $P$. aeruginosa to mutate from a no-mucoid to a constitutively mucoid phenotype (missense GAC65GGC Asp-Gly) as a stress adaptation poses a serious problem for the fresh-cut chain where a broad range of different environmental conditions (stresses) occur between the field and the table. In conclusion, as reported for other foodborne pathogens by different authors [33-37], the evidence is provided that also for $P$. aeruginosa there is need to hurry-up appropriate food safety management systems and fast screening methods, such as PCR real-time analysis [35], able to identify mutated mucA phenotypes, characterized by alginate hyper-production.

\section{Funding}

This research was funded by the project "Real Time Check IV Gamma" - Por Fesr 2014/2020 - Asse Prioritario I "Ricerca Scientifica, Sviluppo Tecnologico e Innovazione”.

\section{Acknowledgments}

This research has no acknowledgment.

\section{Conflicts of Interest}

The authors declare no conflict of interest.

\section{References}

1. Velderrain-Rodríguez, G.R.; Quirós-Sauceda, A.E.; González Aguilar, G.A.; Siddiqui, M.W.; Ayola Zavala, J.F. Technologies in Fresh-cut Fruit and Vegetables. In: Minimally Processed Foods-Food Engineering series. Siddiqui, M.W.; Rahman, M.S. eds. Springer Int Pub 2015, 79-103, https://doi.org/10.1007/978-3-319-106779_5.

2. Machado-Moreira, B.; Richards, K.; Brennan, F.; Abram, F.; . Burgess, C. M. Microbial Contamination of Fresh Produce: What, Where, and How? Comprehensive Reviews in Food Science and Food Safety 2019, https://doi.org/10.1111/1541-4337.12487.

3. Turner, K.; Moua, C N.; Hajmeer, M.; Barnes, A.; Needham, M. Overview of Leafy Greens-Related Food Safety Incidents with a California Link: 1996 to 2016. J Food Prot 2019, 82, 405-414, https://doi.org/10.4315/0362-028X.JFP-18-316

4. Jideani, A.I.O.; Anyasi, T.A.; Mchau, G.R.A.; Udora, E.O.; Onipe, O.O. Processing and Preservation of Fresh-Cut Fruit and Vegetable Products. Kahramonoglu, I. eds Postharvest Handling. InTech, open science/open minds 2017; 47-73, https://doi.org/10.5772/intechopen.69763.

5. Tao, T.; Ding, C.; Han, N.; Cui, Y.; Liu, X.; Zhang, C. Evaluation of pulsed light for inactivation of foodborne pathogens on fresh-cut lettuce: Effects on quality attributes during storage. Food Packaging and Shelf Life 2019, 100358, https://doi.org/10.1016/j.fpsl.2019.100358. 
6. Pinto, L.; Ippolito, A.; Baruzzi, F. Control of spoiler Pseudomonas spp. on fresh cut vegetables by neutral electrolyzed water. Food Microbiol 2015, 50, 102-108, https://doi.org/10.1016/j.fm.2015.04.003.

7. Sant'Anna, P B,; de Melo Franco, B D,; Maffei, D F. J . Microbiological safety of ready-to-eat minimally processed vegetables in Brazil: an overview. Listeria Sci Food Agric 2020, https://doi.org/ 10.1002/jsfa.10438.

8. Hughes, D. Critical review: Selection and evolution of resistance to antimicrobial drugs. Int Union Bioch Mol Biol 2017, 66, 521-529, https://doi.org/10.1002/iub.1278.

9. Ijabadeniyi, O.A.; Debusho, L.K. Vanderlinde, M.; Buys, E.M. Irrigation water as a potential preharvest source of bacterial contamination of vegetables. J Food Safety 2011, 31, 452-461, https://doi.org/10.1111/j.17454565.2011.00321.x.

10. Holvoet, K.; Jacxsens, L.; Sampers, I.; Uyttendaele, M. Insight into the prevalence and distribution of microbial contamination to evaluate water management in fresh produce processing industry. J Food Protec 2012, 75, 671-681, https://doi.org/10.4315/0362-028X.JFP-11-175.

11. Olszewska, M.A.; Koco, A.M.; Stanowcka, A.; Łaniewska-Trokenheim, Ł. Biofilm formation by Pseudomonas aeruginosa and disinfectant susceptibility of planktonic and biofilm cells. Czech J Food Sci 2016, 34, 204-210, https://doi.org/10.17221/528/2015-CJFS.

12. Smith, A.; Hearn, J.;Taylor, C.; Wheelhouse, N.; Kaczmarek, M.; Moorhouse, E.; Singleton, I. Listeria monocytogenes isolates from ready to eat plant produce are diverse and have virulence potential. Int J Food Microbiol 2019, 16;299:23-32, https://doi.org/10.1016/j.ijfoodmicro.

13. Bardin, E.E.; Cameron, S.J.S.; Perdones-Montero, A.; Hardiman, K.; Bolt, F.; Alton, E.W.F.W.; Bush, A.; Davies, J.C.; Takáts, Z. Metabolic phenotyping and strain characterisation of Pseudomonas aeruginosa isolates from cystic fibrosis patients using rapid evaporative ionisation mass spectrometry. Sci Rep 2018, 8, https://doi.org/10.1038/s41598-018-28665-7.

14. Fukushima, H.; Kawase, J.; Etoh, Y.; Sugama, K.; Yashiro, S.; Iida, N.; Yamaguchi, K. Simultaneous screening of 24 target genes of foodborne pathogens in 35 foodborne outbreaks using multiplex real-time SYBR green PCR analysis. Int J Microbiol 2010, 2010, 18, https://doi.org/10.1155/2010/864817.

15. Callejón, R.M.; Rodríguez-Naranjo, M.I.; Ubeda, C.; Hornedo-Ortega, R.; Garcia-Parrilla, C.M.; Troncoso, A.M. Reported Foodborne outbreaks due to fresh produce in the United States and European Union: trends and causes. Foodborne Path Dis 2015, 12, 33-38, https://doi.org/10.1089/fpd.2014.1821.

16. Grobe, S.; Wingender, I.; Flemming, H.C. Capability of mucoid Pseudomonas aeruginosa to survive in chlorinated water. Int J Hyg Environ Health 2001, 204, 139-42, https://doi.org/10.1078/1438-4639-00085.

17. Zhao, X.; Zhaoa,F.; Wangb, J.; Zhongc, N.Biofilm formation and control strategies of foodborne pathogens: food safety perspectives. Royal society of chemistry 2017, 7, 36670-36683, https://doi.org/10.1039/C7RA02497E.

18. Hoffmann, S.; Devleesschauwer, B.; Aspinal, W.; Cooke, R.; Corrigan, T.; Havelaar, A.; Angulo, F.;Gibb, H.; Kirk, M.; Lake, R.; Speybroeck, N.; Torgerson, P.; Hald, T. Attribution of global foodborne disease to specific foods: Findings from a World Health Organization structured expert elicitation. PLoS ONE 2017, 12, https://doi.org/10.1371/journal.pone.0183641.

19. Lake, I.R.; Barker, G.C. Climate change, foodborne pathogens and illness in higher-income countries. Cur Environ Health Rep 2018, 5, 187-196, https://doi.org/10.1007/s40572-018-0189-9.

20. Barberis, A.; Deiana, M.; Spissu, Y.; Azara, E.; Fadda, A.; Serra, P.A.; D’hallewin, G.; Pisano, M.; Serreli, G.; Orrù, G.; Scano, A.; Steri, D.; Sanjust, E. Antioxidant, Antimicrobial, and Other Biological Properties of Pompia Juice. Molecules 2020, 25, 3186. https://doi.org/10.3390/molecules25143186.

21. Kalaiarasan, E.; Kottha, T.; Harish B.N; Gnanasambandam, V.; Sali, V.K.; John, J. Inhibition of quorum sensing-controlled biofilm formation in Pseudomonas aeruginosa by quorum-sensing inhibitors. Microbial Pathogen 2017, 111, 99-107, https://doi.org/10.1016/j.micpath.2017.08.017.

22. Söderqvist, K.; Osman, O.A.; Wolff, C.; Bertilsson, S.; Vågsholm, I.; Boqvist, S. Emerging microbiota during cold storage and temperature abuse of ready-to-eat salad. Infect Ecol Epidemiol 2017, 7, https://doi.org/10.1080/20008686.2017.1328963.

23. Caleb, O.J.; Mahajan, P.V., Al-Julanda, F.; Opara, U.L. Modified atmosphere packaging technology of fresh and fresh-cut produce and the microbial consequences. A Review. Food Bioprocess Technol 2013, 6, 303329, https://doi.org/10.1007/s11947-012-0932-4.

24. Erriu, M.; Pili, F.M.G.; Tuveri, E.; Pigliacampo, D.; Scano, A.; Montaldo, C.; Piras V.; Denotti G.; Pilloni, A.; Garau, V.; Orrù G. Oil Essential Mouthwashes Antibacterial Activity Against Aggregatibacter Actinomycetemcomitans: A Comparison Between Antibiofilm and Antiplanktonic Effects. Int J Dent 2013, 2013, https://doi.org/10.1155/2013/164267.

25. Pilloni, A.; Carere, M.; Orrù G.; Scano, A.; Trezza C.; Mariana, A.R.; Zeza B. Adjunctive Use of an Ethyl Lauroyl arginate-(LAE-)-containing Mouthwash in the Nonsurgical Therapy of Periodontitis: A Randomized Clinical Trial. Minerva Stomatol 2018, 67, 1-11. doi: 10.23736/S0026-4970.17.04084-5.

26. Denotti, G.; Piga, R.; Montaldo, C.; Erriu, M.; Pilia, F.; Piras, A.; Luca, M.D.; Orrù, G. In Vitro evaluation of Enterococcus faecalis adhesion on various endodontic medicaments. Open Dent $J$ 2009, 9, 120-124, https://doi.org/10.2174/1874210600903010120. 
27. Yuan,W.; Teo, C.H.M.;Yuk, H.G. Combined antibacterial activities of essential oil compounds against Escherichia coli O157:H7 and their application potential on fresh-cut lettuce. Food Control 2019, 96, 112118, https://doi.org/10.1016/j.foodcont.2018.09.005.

28. Sharma, M.; Lakshman, S.; Ferguson, S.; Ingram, DT.; Luo, Y.; Patel, J. Effect of modified atmosphere packaging on the persistence and expression of virulence factors of Escherichia coli O157:H7 on shredded Iceberg lettuce. J Food Prot 2011, 74, 718-726, https://doi.org/10.4315/0362-028X.JFP-10-427.

29. Damron, F.H.; Goldberg, J.B. Proteolytic regulation of alginate overproduction in Pseudomonas aeruginosa Molec Microbiol 2012, 84, 595-607, https://doi.org/10.1111/j.1365-2958.2012.08049.x.

30. Lim, J.; Cui, Y.; Oh, Y.J.; Park, J.R.; Jo, W.; Cho, Y.H. Park, S. Studying the effect of alginate overproduction on Pseudomonas aeruginosa biofilm by atomic force microscopy. J Nanosci Nanotechnol 2011, 11, 5676-81, https://doi.org/10.1166/jnn.2011.4491.

31. Worlitzsch, D.; Tarran, R.; Ulrich, M.; Schwab, U.; Cekici, A.; Meyer, K.C.; Birrer, P.; Bellon, G.; Berger, J.; Weiss, T.; Botzenhart, K.; Yankaskas, J.R.; Randell, S.; Boucher, R.C.; Döring, G. Effect of reduced mucus oxygen concentration in airway Pseudomonas infections of cystic fibrosis patients. J Clin Invest 2002, 109, 317-325, https://doi.org/10.1172/JCI13870.

32. Oyinlola, L.A.; Obadina, A.O.; Omemu, A.M.; Oyewole, O.B. Prevention of microbial hazard on fresh-cut lettuce through adoption of food safety and hygienic practices by lettuce farmers. Food Sci Nutri 2017, 5, 6775, https://doi.org/10.1002/fsn3.365.

33. Tatsika, S.; Karamanoli, K.; Karayanni, H.; Genitsaris, S. Metagenomic characterization of bacterial communities on ready-to-Eat vegetables and effects of household washing on their diversity and composition. Pathogens 2019, 8, https://doi.org/10.3390/pathogens8010037.

34. Wright EA, Di Lorenzo V, Trappetti C, et al. Divergence of a strain of Pseudomonas aeruginosa during an outbreak of ovine mastitis. Vet Microbiol. 2015;175 (1):105-113, doi:10.1016/j.vetmic.2014.11.011.

35. Miceli, A.; Gaglio, R.; N Hudson Francesca, Ciminata, A.; Moschetti, G.; Settanni, L. Evolution of shelf life parameters of ready-to-eat escarole (Cichorium endivia var. latifolium) subjected to different cutting operations. Scientia Horticulturae 2019, 247,175-183, https://doi.org/10.1016/j.scienta.2018.12.023.

36. Vataščinová, T.; Pipová, M.; Fraqueza, M.J.R.; Dudrikova, E.; Drazovska, M.; Laukova, A. Short communication: Antimicrobial potential of Lactobacillus plantarum strains isolated from Slovak raw sheep milk cheeses. J Dairy Sci 2020, 103, 6900-6903, https://doi.org/10.3168/jds.2019-17862.

37. Scano, A.; Orrù, G.; Serafi, G.; Occhinegro, A.; Ratto, D.; Girometta, C.; Rossi, P. Long non-coding RNAs: possible parallel paths by E-cadherin expression in colon cancer development as well as in Pseudomonas aeruginosa infection. Eur Rev Med Pharmacol Sci 2018, 22, 5053-5055. https://doi.org/10.26355/eurrev_201808_15696. 